\title{
Microbial quality of water in rural communities of Trinidad
}

\author{
Pedro Welch, ${ }^{1}$ Joanna David, ${ }^{1}$ Wayne Clarke, ${ }^{1}$ Aaron Trinidade, ${ }^{1}$ \\ Dana Penner, ${ }^{1}$ Sean Bernstein, ${ }^{1}$ Laura McDougall, ${ }^{1}$ \\ and Abiodun A. Adesiyun ${ }^{2}$
}

ABSTRACT A cross-sectional study was conducted in four rural communities of northeastern Trinidad to determine the microbial quality of water supply to households and that quality's relationship to source and storage device. Of the 167 household water samples tested, total coliforms were detected in 132 of the samples (79.0\%), fecal coliforms in $102(61.1 \%)$, and E. coli in 111 $(66.5 \%)$. There were significant differences among the towns in the proportion of the samples contaminated with coliforms $(\mathrm{P}<0.001)$ and E. coli $(\mathrm{P}<0.001)$. Of 253 strains of $\mathrm{E}$. coli studied, $4(1.6 \%)$ were mucoid, 9 (3.6\%) were hemolytic, and $37(14.6 \%)$ were nonsorbitol fermenters. Of 69 isolates of E. coli tested, 10 (14.5\%) were verocytotoxigenic. Twenty-eight $(14.0 \%)$ of 200 E. coli isolates tested belonged to enteropathogenic serogroups. Standpipe, the most common water source, was utilized by 57 (34.1\%) of the 167 households. Treated water (pipeborne in homes, standpipes, or truckborne) was supplied to 119 households $(71.3 \%)$, while 48 households $(28.7 \%)$ used water from untreated sources (rain, river/stream, or well) as their primary water supply. The type of household storage device was associated with coliform contamination. Water stored in drums, barrels, or buckets was more likely to harbor fecal coliforms ( $74.2 \%$ of samples) than was water stored in tanks (53.3\% of samples), even after controlling for water source $(\mathrm{P}=0.04)$. Compared with water from other sources, water piped into homes was significantly less likely to be contaminated with total coliforms $(56.9 \%$ versus $88.8 \%, \mathrm{P}<0.001)$ and fecal coliforms $(41.2 \%$ versus $69.8 \%, \mathrm{P}<0.01)$, even when the type of storage device was taken into account. However, fecal contamination was not associated with whether the water came from a treated or untreated source. We concluded that the drinking water in rural communities in Trinidad was grossly unfit for human consumption, due both to contamination of various water sources and during household water storage.

Water can serve as a vehicle for spreading illness caused by such mi-

\footnotetext{
1 University of the West Indies, Faculty of Medical Sciences, School of Medicine, St. Augustine, Trinidad and Tobago.

2 University of the West Indies, Faculty of Medical Sciences, School of Veterinary Medicine, St. Augustine, Trinidad and Tobago. Send correspondence to: Professor A. A. Adesiyun, School of Veterinary Medicine, Faculty of Medical Sciences, University of the West Indies, St. Augustine, Trinidad and Tobago; telephone: (868) 645-9865; fax: (868) 645-7428; e-mail: abiodunadesiyun@hotmail.com
}

croorganisms as Vibrio cholera, Yersinia enterocolitica, Escherichia coli, and Cryptosporidium sp. (1-4). Fecal contamination, combined with the failure to adequately treat water, has been incriminated in many waterborne epidemics $(5,6)$.

Escherichia coli, particularly those possessing such virulence markers as hemolysin production and verocytotoxin production and belonging to the enteropathogenic serogroups, have been responsible for gastroenteritis in humans (7-9).

The worldwide interest in the quality of drinking water stems from the documented association between contaminated water and diarrheal diseases (10). Diminished water quality is associated with factors such as economics and geographical location $(10,11)$.

Demographics differ between rural and urban communities, with rural areas generally having higher propor- 
tions of children and elderly persons (12). Those most susceptible to waterborne enteric infections are children, the elderly, pregnant women, and immunocompromised individuals (12), so the need to ensure potable water supply to these groups is a priority $(12,13)$.

Information on the water quality status in many countries in Latin America and the Caribbean is not readily available, but it has been estimated that $40 \%$ of the population consume water of substandard quality (14). Water supplied to rural communities worldwide is generally of poorer quality than that in urban areas (15-17). In Trinidad and Tobago, there is a dearth of information on the microbial quality of water provided to the population, while virtually nothing is known about the sources of water and water quality at the rural community level.

This study had two specific objectives: 1$)$ to use coliform counts to de- termine the microbial quality of water supplies in four rural communities in Trinidad and 2) to determine the relationships among water source, storage device, and microbial water quality. We also tried to describe virulence markers of E. coli isolates and to determine the frequency of enteropathogenic and verocytotoxigenic strains.

\section{MATERIALS AND METHODS}

\section{Period of study}

The investigation was conducted in March and April 1998, during the dry season in Trinidad.

\section{Water treatment}

The Water and Sewerage Authority (WASA) is responsible for water treat- ment and distribution in Trinidad and Tobago. Chlorination is used to disinfect water piped and trucked to homes and provided by standpipes. Households that obtain their water from other sources (rainwater, rivers, springs, and wells) may or may not treat it themselves.

\section{Survey of rural towns}

The study was conducted in the administrative areas ("wards") of Toco and Matura, situated on the northeastern coast of Trinidad (Figure 1). Trinidad is the larger of the two islands that make up the nation of Trinidad and Tobago. According to 1990 census figures (18), Toco and Matura had a combined population of 7462 . We studied the four major towns in the two administrative areas, Matura (1 257 inhabitants) and Salybia (229 in-

FIGURE 1. Map of Trinidad showing the population density by administrative area, with magnification of sampling areas

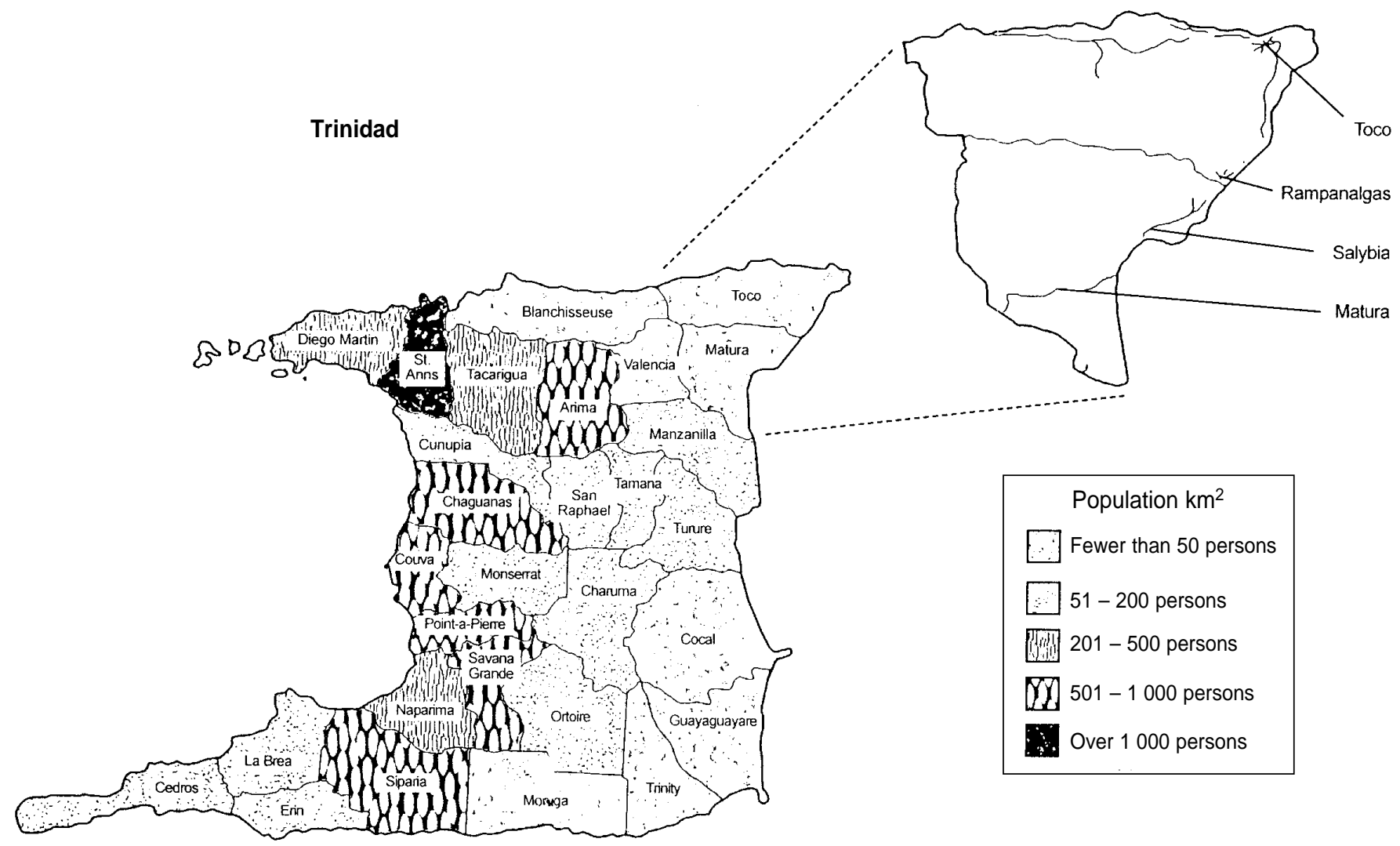


habitants) in Matura, and Rampanalgas (297 inhabitants) and Toco (955 inhabitants).

Our selection of these two administrative areas for our research was based on three criteria. Firstly, both areas are rural, as defined by the Central Statistical Office (CSO) of Trinidad and Tobago, that is, with fewer than 50 individuals per $\mathrm{km}^{2}$. Secondly, the areas have a diversity of water supplies, representative of those found on Trinidad. Lastly, enough demographic information was available to allow for adequate statistical design of the study, particularly the sample size determination.

\section{Sampling design}

The sample size of 167 households was based on an estimated prevalence of coliform contamination of $7.8 \%$ (19), a desired level of precision of $4 \%$, and $\alpha$ set at 0.05 .

In each town, the first house at the end of a randomly chosen street was selected for sampling, followed by the systematic random sampling of every fifth house along the same street. If the residents of the fifth house did not respond, the next house in sequence after that one was targeted. The process of sampling every fifth household was then continued, counting from the nonrespondent household. For this investigation, nonrespondents were those households that could not or would not participate in the study for whatever reason or reasons. The number of samples taken from each town was proportional to each town's population.

\section{Questionnaire administration}

A comprehensive questionnaire was administered to each selected household. The questionnaire included such variables as family size, age distribution of family members, the number of years the family had lived in that house, main source of drinking water, and treatment and storage of water.
We interviewed a volunteer in each household who was able to provide adequate information for the survey.

\section{Laboratory investigation}

The laboratory component of the study was carried out in accordance with the method of the Environmental Protection Agency (EPA) of the United States of America (20).

\section{Sample collection, transportation, and storage}

In each selected household, $250 \mathrm{~mL}$ of water was sampled in the form usually consumed by inhabitants. For pipeborne water, taps were allowed to run for 1 minute before water was aseptically collected into sterile widemouth glass bottles. Drinking water the households stored in bottles or other containers was poured into the sample bottles. All samples were transported to the laboratory ice-cooled and were processed within 6 hours of collection.

\section{Enumeration of coliforms}

For the enumeration of coliforms, the EPA procedure was used (20). Endo agar and mFC agar (Difco, Detroit, Michigan, United States) were used to detect total coliforms and fecal coliforms, respectively, following millipore filtration $(0.45 \mu \mathrm{m})$ and incubation at $37^{\circ} \mathrm{C}$ and $44.5^{\circ} \mathrm{C}$, respectively. For each sample, $100 \mathrm{~mL}$ of water was initially filtered, but when the coliforms were too numerous to count, 50 $\mathrm{mL}$ of water was filtered. All counts were expressed as either total or fecal coliforms per $100 \mathrm{~mL}$ of water. All water samples having one or more coliforms per $100 \mathrm{~mL}$ were judged to be of poor quality, based on the zero tolerance level for coliforms in water that the EPA advocates (20).

To detect E. coli, all colonies of coliforms which showed characteristic appearance on endo agar and $\mathrm{mFC}$ agar were subcultured on eosin methylene blue (EMB) agar, incubated over-night at $37^{\circ} \mathrm{C}$, and subjected to biochemical tests to identify E. coli $(21,22)$.

\section{Characterization of $E$. coli isolates}

To detect mucoid and hemolytic strains of $E$. coli, all isolates were plated on sheep blood agar plates and incubated overnight at $37^{\circ} \mathrm{C}$. The appearance of mucoid-looking colonies and those with complete clearing (hemolytic) was noted. Similarly, Sorbitol MacConkey agar was inoculated with E. coli and incubated overnight at $37^{\circ} \mathrm{C}$. Colorless or cream-appearing colonies were classified as nonsorbitol fermenters (NSF), and pink colonies were considered sorbitol fermenters (SF).

To detect $\mathrm{O} 157$ strains of E. coli among isolates, the slide agglutination test was performed using E. coli O157 antiserum (Difco, Detroit, Michigan, United States).

To grow E. coli isolates for toxin production, a loopful of 69 randomly selected isolates was each inoculated into $20 \mathrm{~mL}$ of brain heart infusion broth and incubated on a gyratory shaker in a water bath (Forma Scientific, Marietta, Ohio, United States) at $37^{\circ} \mathrm{C}$ overnight as described earlier (23). The broth cultures were spun down in a centrifuge at $15000 \times \mathrm{g}$ for $15 \mathrm{~min}$, and the supernatant was assayed for verocytotoxin (VT) using Vero cell monolayers with appropriate negative and positive controls (24). To detect $E$. coli isolates that belonged to enteropathogenic serogroups, 200 isolates of $E$. coli were randomly selected from the four towns, based on the number of isolates, and were tested by slide agglutination tests using E. coli polyvalent antisera A and B (Central Veterinary Laboratory, Weybridge, Surrey, United Kingdom).

\section{Analysis of data}

In view of the high counts of total coliforms, and as suggested earlier (16), samples were classified as good/ 
fair (0-20 total coliforms per $100 \mathrm{~mL}$ ), poor (21-100 total coliforms per 100 $\mathrm{mL}$ ), and very poor (over 100 total coliforms per $100 \mathrm{~mL}$ ). For fecal coliforms, the categories used were good/ fair (0-5 fecal coliforms per $100 \mathrm{~mL})$, poor (6-20 fecal coliforms per $100 \mathrm{~mL}$ ), and very poor (over 20 fecal coliforms per $100 \mathrm{~mL}$ ).

Demographic parameters, water management variables, and water quality were compared among the four towns. Analysis of variance (ANOVA) was used to compare household size and the length of residence in the town, and Kruskal-Wallis one-way ANOVA was used to compare the distribution of water sources, the storage devices used, and the use of boiling or some other form of home treatment of water. The chi-square test was used to compare the prevalence of total coliforms and fecal coliforms that exceeded recommended limits (20) and the presence of virulence markers among $E$. coli strains isolated from the four towns.

The association between storage device and contamination of water was tested using a Mantel-Haenszel stratified analysis, controlling for source of water. To investigate the relationship between source of drinking water and contamination with total or fecal coliforms, a Mantel-Haenszel stratified analysis was also used, stratifying by storage device.

Epi Info version 6.04 (U.S. Centers for Disease Control and Prevention,
Atlanta, Georgia, United States) was used for data analysis, and $P$ values less than 0.05 were considered statistically significant.

\section{RESULTS}

One hundred and sixty-seven households in the wards of Toco and Matura participated in the study. Of the 164 households with known household size, 59 (36.0\%) had 1-3 residents, $62(37.8 \%)$ had $4-6$ residents, and $43(26.2 \%)$ had more than 6 residents (Table 1). Household size did not vary significantly among the four towns studied, and there were no significant differences among the towns

TABLE 1. Household demographic data and water source, storage, and treatment (number of households and percent), four towns, northeastern Trinidad, 1998

\begin{tabular}{|c|c|c|c|c|c|c|c|c|c|c|c|}
\hline \multirow{2}{*}{$\begin{array}{c}\text { Characteristic } \\
\text { [Households } \\
\text { providing information] }\end{array}$} & \multicolumn{2}{|c|}{ Matura } & \multicolumn{2}{|c|}{ Rampanalgas } & \multicolumn{2}{|c|}{ Salybia } & \multicolumn{2}{|c|}{ Toco } & \multicolumn{2}{|c|}{ Total } & \multirow{2}{*}{$\begin{array}{l}\text { Significance } \\
\text { value of } \\
\text { differences } \\
\text { among towns }\end{array}$} \\
\hline & No. & $\%$ & No. & $\%$ & No. & $\%$ & No. & $\%$ & No. & $\%$ & \\
\hline Household size [164] & & & & & & & & & & & 0.17 \\
\hline $1-3$ & 23 & 35.9 & 8 & 26.7 & 11 & 55.0 & 17 & 34.0 & 59 & 36.0 & \\
\hline $4-6$ & 23 & 35.9 & 10 & 33.3 & 8 & 40.0 & 21 & 42.0 & 62 & 37.8 & \\
\hline$>6$ & 18 & 28.1 & 12 & 40.0 & 1 & 5.0 & 12 & 24.0 & 43 & 26.2 & \\
\hline Time lived in that household [161] & & & & & & & & & & & 0.38 \\
\hline$<6$ years & 9 & 13.8 & 7 & 24.1 & 2 & 10.0 & 10 & 21.3 & 28 & 17.4 & \\
\hline $6-15$ years & 14 & 21.5 & 4 & 13.8 & 2 & 10.0 & 7 & 14.9 & 27 & 16.8 & \\
\hline $16-30$ years & 7 & 10.8 & 4 & 13.8 & 4 & 20.0 & 12 & 25.5 & 27 & 16.8 & \\
\hline$>30$ years & 35 & 53.8 & 14 & 48.3 & 12 & 60.0 & 18 & 38.3 & 79 & 49.1 & \\
\hline $\begin{array}{l}\text { Source of drinking water [167] } \\
\text { Water and Sewerage Authority } \\
\text { (WASA) }\end{array}$ & & & & & & & & & & & $<0.001^{a}$ \\
\hline Piped & 15 & 22.4 & 4 & 13.3 & 1 & 5.0 & 31 & 62.0 & 51 & 30.5 & \\
\hline Standpipe & 26 & 38.8 & 15 & 50.0 & 3 & 15.0 & 13 & 26.0 & 57 & 34.1 & \\
\hline Truck & 5 & 7.5 & 1 & 3.3 & 4 & 20.0 & 1 & 2.0 & 11 & 6.6 & \\
\hline Non-WASA & & & & & & & & & & & \\
\hline Rain & 11 & 16.4 & 6 & 20.0 & 8 & 40.0 & 4 & 8.0 & 29 & 17.4 & \\
\hline River/Spring & 9 & 13.4 & 4 & 13.3 & 4 & 20.0 & 1 & 2.0 & 18 & 10.8 & \\
\hline Well & 1 & 1.5 & 0 & 0.0 & 0 & 0.0 & 0 & 0.0 & 1 & 0.6 & \\
\hline Household water-storage device [166] & & & & & & & & & & & $0.01^{b}$ \\
\hline Tank & 41 & 61.2 & 11 & 36.7 & 14 & 70.0 & 39 & 79.6 & 105 & 63.3 & \\
\hline Barrel/Drum & 12 & 17.9 & 11 & 36.7 & 3 & 15.0 & 5 & 10.2 & 31 & 18.7 & \\
\hline Bucket & 13 & 19.4 & 8 & 26.7 & 3 & 15.0 & 5 & 10.2 & 29 & 17.5 & \\
\hline None & 1 & 1.5 & 0 & 0.0 & 0 & 0.0 & 0 & 0.0 & 1 & 0.6 & \\
\hline Water treatment by the household & & & & & & & & & & & \\
\hline$[159]$ & & & & & & & & & & & 0.15 \\
\hline Yes & 20 & 31.7 & 14 & 50.0 & 6 & 31.6 & 12 & 24.5 & 52 & 32.7 & \\
\hline No & 43 & 68.3 & 14 & 50.0 & 13 & 68.4 & 37 & 75.5 & 107 & 67.3 & \\
\hline
\end{tabular}

a WASA water compared with water from untreated sources.

${ }^{\mathrm{b}}$ Households using no storage device excluded from analysis. 
in the average length of time householders had lived in the area.

All 167 households provided information pertaining to their most commonly used source of water. A standpipe was the most frequently used source $(34.1 \%)$, while well water was the least common $(0.6 \%)$. Pipeborne water supplied by the Water and Sewerage Authority (WASA) and piped directly into residents' homes was used by a total of 51 households (30.5\%). Among the four towns, there were significant differences in the proportion of households utilizing water provided by WASA (pipe, standpipe, or truck) $(P<0.001)$, as well as in the proportion of households receiving pipeborne water from WASA $(P<0.001)$. Toco had the highest proportion of households using WASA water $(90.0 \%)$ and WASA pipeborne water $(62.0 \%)$, while households in Salybia were least likely to use WASA water $(40.0 \%)$ and WASA pipeborne water $(5.0 \%)$.

Of the 166 households that responded to the question pertaining to water storage practices, 105 households $(63.3 \%)$ reported storing water in water tanks, 31 households (18.7\%) utilized drums or barrels, and 29 households $(17.5 \%)$ reported that buckets were their main storage device. One household did not store water at all.

Out of the 159 households that indicated their water treatment practices, $107(67.3 \%)$ did not routinely treat their water. Of the 52 households $(32.7 \%)$ that did treat their drinking water, boiling was the preferred method, used by 32 of those 52 households. Of the remaining 20 households, 17 of them used bleach/chlorine, 2 preferred boiling and bleach, and 1 filtered. Households receiving WASA water were more likely to report treating the water themselves (41 of 115 households, or $35.7 \%$ ) than were households receiving water from untreated sources (11 of 44 households, or $25.0 \%$ ), but that difference was not statistically significant $(P=0.20)$.

Considering total coliform counts, $38.3 \%$ of water samples tested in this study were classified in the good/ fair category, $12.0 \%$ were poor, and $49.7 \%$ were very poor. The breakdowns for the four towns are illustrated in Figure 2, for both total coliforms and for fecal coliforms. There were significant differences in total coliform counts $(P<$ $0.001)$ and fecal coliform counts $(P<$ 0.001 ) among the four towns. For both total and fecal coliform counts per 100 $\mathrm{mL}$, Toco had the highest proportion of water samples in the good/fair category (both $80.0 \%$ ) while Rampanalgas had the lowest proportion of samples in this category (both 16.7\%).

According to the EPA standard of zero total coliforms (20), 132 (79.0\%) of 167 households were utilizing water unfit for human consumption. There were significant differences $(P<0.001)$ among the towns in the proportion of households with any coliforms in the drinking water sampled. The proportions ranged from $42.0 \%$ of households in Toco to $100 \%$ of households in Salybia (Figure 3). Overall, 102 (61.1\%) of the households had water supplies contaminated by fecal coliforms, and $111(66.5 \%)$ of them had water supplies contaminated by E. coli. The prevalence of fecal coliform contamination in water ranged from $32.0 \%$ in

FIGURE 2. Number of households with various levels of drinking water quality in four rural towns, in terms of total and fecal coliform counts, northeastern Trinidad, 1998
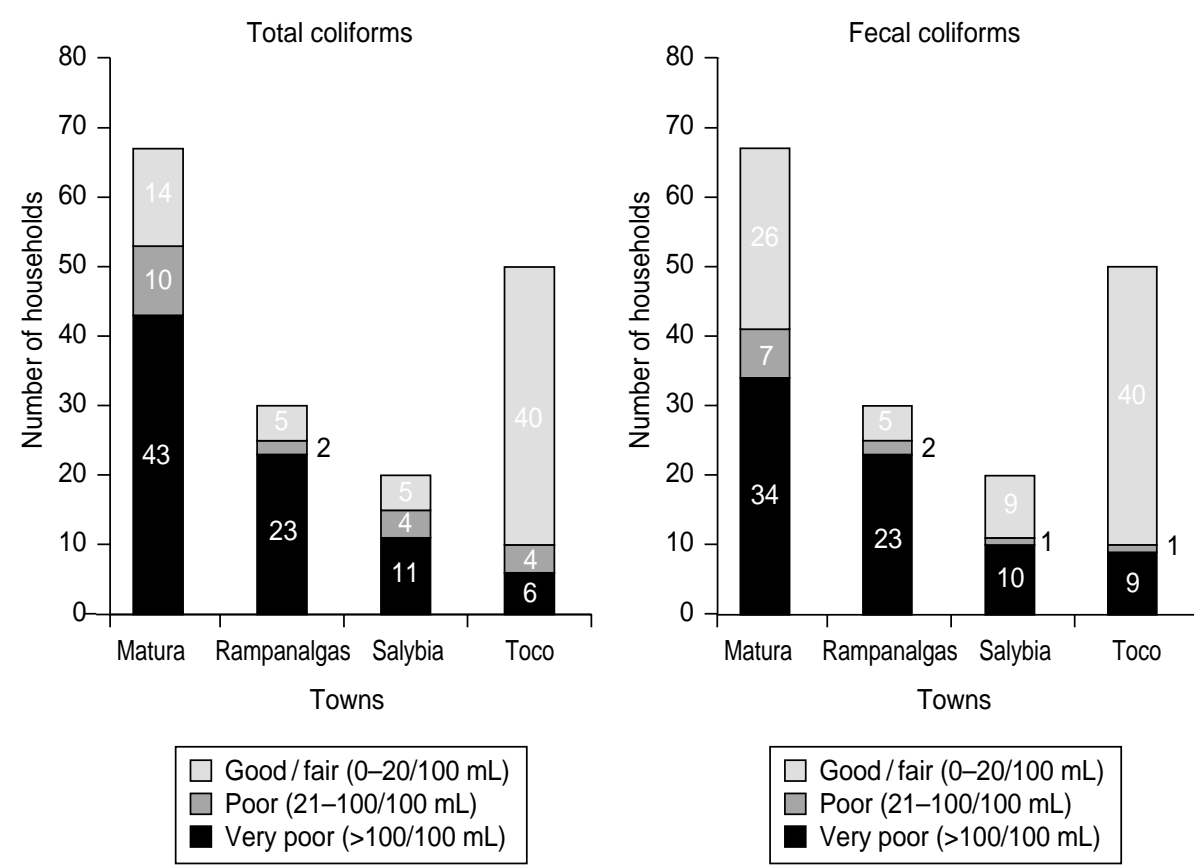

Toco to $90.0 \%$ in Rampanalgas, and the difference in prevalence among the towns was statistically significant $(P<0.001)$. E. coli was detected in the drinking water of $28.0 \%$ of households in Toco, compared with $86.7 \%$ of households in Rampanalgas. The difproportion of households with E. coli detected in the drinking water was statistically significant $(P<0.001)$.

Water stored in tanks was significantly more likely $(P=0.04)$ to have been water piped directly into the home $(36.2 \%)$ than was water stored in other devices (21.0\%). Figure 4 shows the coliform contamination of water by source and by storage device. Drinking water stored in tanks was significantly less likely to be contaminated by total coliforms $(72.4 \%)$ than was water stored in buckets, drums, or barrels (90.3\%), even after adjusting for water source $(P<0.01)$. Water from tanks was also significantly less likely to be positive for fecal coliforms (53.3\%) compared with water from other storage devices $(74.2 \%)$, even after controlling for water source $(P=0.01)$. ference among the four towns in the 
FIGURE 3. Percentage of households from four rural towns with total coliforms, fecal coliforms, and E. coli in drinking water, Trinidad, 1998

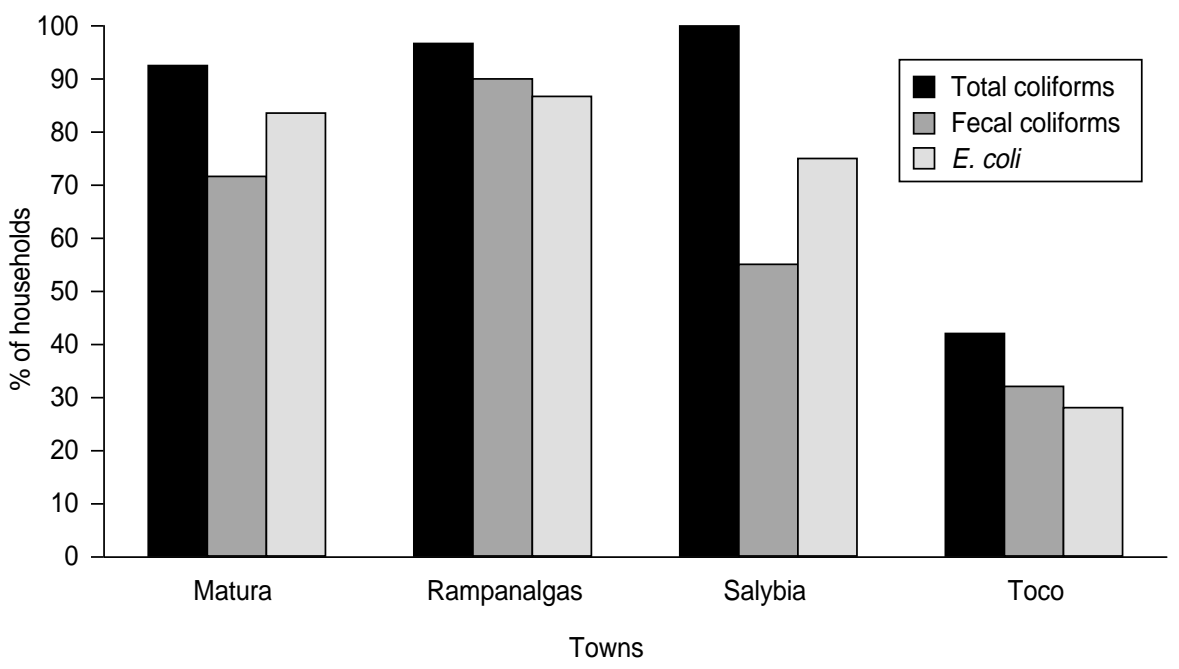

FIGURE 4. Percentage of samples contaminated with total and fecal coliforms, by water source and storage device, Trinidad, 1998

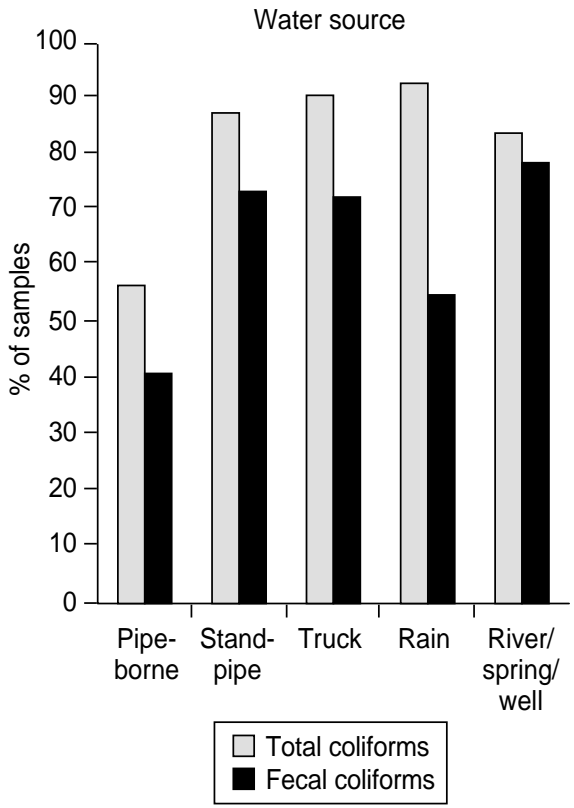

WASA water piped directly to residents' homes was less likely to be contaminated by total coliforms (56.9\%) than was water from all other sources combined $(88.8 \%)$. This difference was significant, even after controlling for storage device in a stratified analysis $(P<0.001)$. Similarly, $41.2 \%$ of samples taken from homes with a direct, pipe-

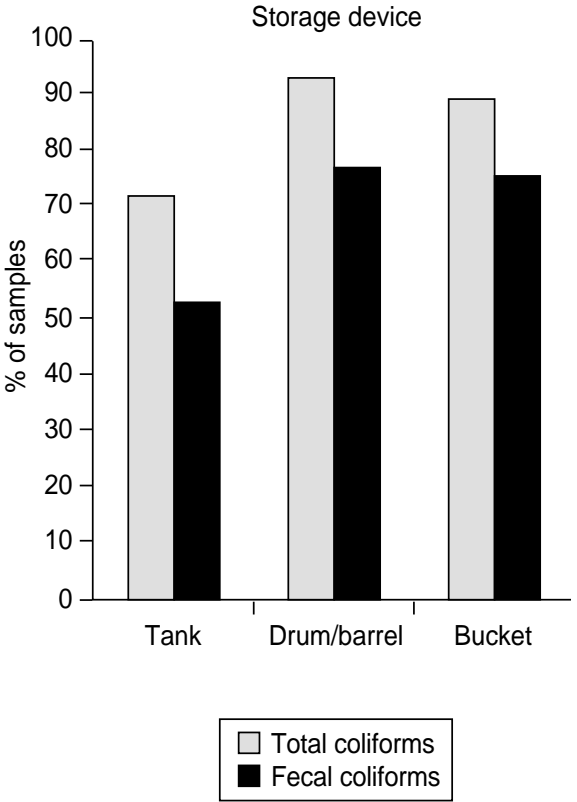

borne WASA water supply were contaminated by fecal coliforms, compared with $69.8 \%$ of samples from all other homes. This difference was also significant after controlling for storage device $(P<0.01)$.

Total coliforms were more likely to be detected in water from an untreated source $(89.6 \%)$ than in WASA water
(74.8\%), a difference that was statistically significant even after adjusting for storage device $(P=0.04)$. However, there was no significant difference in fecal coliform contamination between water from WASA and water from non-WASA sources.

The prevalence of virulence markers and enteropathogenic strains of E. coli isolates is shown in Table 2. Of a total of 253 isolates of $E$. coli studied, 4 $(1.6 \%)$ were mucoid, $9(3.6 \%)$ were hemolytic, and 37 (14.6\%) were nonsorbitol fermenters (NSF). Of the $200 E$. coli isolates tested for enteropathogenic strains, $28(14.0 \%)$ belonged to the enteropathogenic serogroups. The difference in the prevalence of enteropathogenic strains among towns was not statistically significant.

Of 69 isolates of E. coli tested for verocytotoxigenicity from the four towns, $10(14.5 \%)$ were verocytotoxigenic. Isolates from Matura had the highest frequency of verocytotoxigenicity (6 of $29,20.7 \%$ ), while none of the four isolates from Salybia was verocytotoxigenic.

Only $5(2.0 \%)$ of a total of 253 E. coli isolates tested were O157 strains, with $2(1.4 \%)$ of 139 isolates from Matura and $3(5.4 \%)$ of 56 isolates from Rampanalgas agglutinated by $\mathrm{O} 157$ antiserum.

\section{DISCUSSION}

Based on the presence of total coliforms (79\% of households) and fecal coliforms (61\% of households), a substantial proportion of rural households were found to have drinking water considered unfit for human consumption. This was even true for households receiving treated, pipeborne water distributed by the Water and Sewage Authority (WASA), where total coliforms were detected in $57 \%$ of samples and fecal coliforms were detected in $41 \%$ of samples.

Water destined for human consumption should be free of coliforms (20). The health implications of waterborne coliform contamination cannot be overemphasized. The presence of coliforms in water is an indication of fecal contami- 
TABLE 2. Characteristics of $E$. coli strains isolated from drinking water in four towns, northeastern Trinidad, 1998

\begin{tabular}{|c|c|c|c|c|c|c|c|c|c|c|c|c|}
\hline \multirow[b]{3}{*}{ Town } & \multicolumn{9}{|c|}{ E. coli isolates with virulence markers } & \multicolumn{3}{|c|}{ Enteropathogenicity } \\
\hline & \multirow{2}{*}{$\begin{array}{l}\text { No. of } E \text {. coli } \\
\text { isolates tested }\end{array}$} & \multicolumn{2}{|c|}{ Mucoid } & \multicolumn{2}{|c|}{ Hemolytic } & \multicolumn{2}{|c|}{ NSFa $^{a}$} & \multicolumn{2}{|c|}{ O157 strain ${ }^{b}$} & \multirow{2}{*}{$\begin{array}{l}\text { No. of } E \text {. coli } \\
\text { isolates tested }\end{array}$} & \multicolumn{2}{|c|}{ EPEC strains $^{\circ}$} \\
\hline & & No. & $\%$ & No. & $\%$ & No. & $\%$ & No. & $\%$ & & No. & $\%$ \\
\hline Matura & 139 & 0 & 0.0 & 6 & 4.3 & 16 & 11.5 & 2 & 1.4 & 97 & 13 & 13.4 \\
\hline Rampanalgas & 56 & 2 & 3.5 & 2 & 3.5 & 16 & 28.6 & 3 & 5.4 & 47 & 6 & 12.8 \\
\hline Salybia & 29 & 1 & 3.4 & 1 & 3.4 & 2 & 6.1 & 0 & 0.0 & 29 & 3 & 10.3 \\
\hline Toco & 29 & 1 & 3.4 & 0 & 0.0 & 3 & 10.3 & 0 & 0.0 & 27 & 6 & 22.2 \\
\hline Total & 253 & 4 & 1.6 & 9 & 3.6 & 37 & 14.6 & 5 & 2.0 & 200 & 28 & 14.0 \\
\hline
\end{tabular}

a NSF = nonsorbitol fermenters

${ }^{\mathrm{b}} \mathrm{O} 157$ strains of $E$. coli agglutinated by $E$. coli 0157 antiserum.

${ }^{c} \mathrm{EPEC}=$ enteropathogenic $E$. coli.

nation and has been associated with waterborne epidemics in humans $(1,4,25)$.

The rather high proportion of households supplied with treated pipeborne water distributed by WASA that is unfit for human consumption may be a reflection of several factors. Both inadequate chlorination of water at treatment plants and posttreatment contamination along the water distribution line can result in coliforms in water $(26,27)$. A third factor may be that almost all of the water supplied to households was kept in some form of storage device. Having unsanitary storage containers is known to contribute to substantial reductions in water quality (28).

In our research, the water stored in tanks was of significantly higher quality than water stored in buckets, barrels, or drums, even after controlling for water source. This strongly suggests the role of containers in the contamination process, since tanks are usually covered, and the other storage devices are frequently left uncovered and subject to contamination.

Despite the high level of contamination of pipeborne water that WASA provided directly to residents' homes, this water was of a significantly higher quality than water provided by all other sources, even after the households' primary method of water storage was taken into account. However, fewer than one-third of the households in these two administrative areas of the island received this superior pipeborne water.

When all of the WASA water sources were grouped together (pipeborne, standpipe, and truckborne) and compared with water from untreated sources, no significant difference in fecal coliform contamination was found. This suggests that contamination occurred in the trucks themselves or in the containers used by residents to transport water from standpipes to the storage containers used at home.

The vast majority of households supplied by river, spring, or well water had drinking water considered unfit for human consumption, based on the presence of total coliforms $(84 \%)$ and fecal coliforms (79\%). All of the rivers or springs in question were located less than $400 \mathrm{~m}$ from a road or a household. Furthermore, in Matura a latrine was less than $27 \mathrm{~m}$ from a river from which some households in the study collected drinking water. Closeness of toilets or latrines to water sources can result in water contamination (15).

It is alarming that of the 167 households sampled, 132 of them $(79.0 \%)$ were consuming water considered unfit by international standards (20). This situation is further compounded by the fact that only about one-third of the households that were surveyed used any of the various treatments that could improve water quality (13, $17,26,29)$. The presence of coliforms in a high proportion of water samples is a good indicator of water contamination. This, coupled with the detection of $E$. coli in approximately two-thirds of the water samples, is also cause for concern since $E$. coli is an enteric pathogen responsible for gastroenteritis in humans (7).

It was of etiologic significance that a number of the strains of E. coli isolated exhibited virulence markers, such as mucoid and hemolytic colonies, which are associated with pathogenicity (30, 31). The frequency of these two virulence markers among the isolates of $E$. coli appears low, with $1.6 \%$ producing mucoid colonies and $3.6 \%$ hemolytic. However, the possibility of expression of other virulence markers, not assayed for, cannot be ignored (32-35).

Compared with other virulence markers studied among the isolates of E. coli, nonsorbitol fermentation was the most prevalent. It has been reported to be a phenotypic characteristic of E. coli O157:H7 strains that elaborate verocytotoxins (35). It was therefore very significant that $14 \%$ of 69 isolates of $E$. coli tested were verocytotoxigenic, a first documentation of this type of E. coli from water sources in Trinidad and Tobago. Verocytotoxigenic E. coli (VTEC) or E. coli O157 strains, however, have been isolated from meat and milk and from dairy cattle in the country (36-38). It is well documented that non-O157 strains of E. coli also produce verocytotoxins (38). Waterborne outbreaks of gastroenteritis due to VTEC strains have occurred elsewhere $(39,40)$. It is also clinically significant that $14 \%$ of the E. coli isolates in the current study belonged to enteropathogenic serogroups. These strains of E. coli are known to cause diarrhea in humans $(7,41)$.

Based on the observation that $79 \%$ of households had water supplies unfit for human consumption, that only $32 \%$ of the households treat their water in any manner, and that we iso- 
lated E. coli strains that are verocytotoxigenic and belong to enteropathogenic serogroups, we conclude that a great potential exists for waterborne gastroenteritis in Trinidad. There is, therefore, an urgent need to improve the quality of water supply to the administrative areas of Toco and Matura.

The following four-point approach is suggested for improving the quality of water supplied to the rural communities studied:

- enhance the provision of pipeborne water, since this source was found to be of a higher quality than other sources
- investigate the source of contamination of pipeborne water supplies, to delineate the roles of the water delivery system and of household water storage systems

- institute a system to monitor the quality of untreated water sources so that water collection can be restricted to uncontaminated sources and/or water treatment advisories can be issued appropriately

- educate the public on appropriate water handling, storage, and treatment methods

It is evident that until these recommendations are implemented, water supplied to rural communities in Trinidad will continue to pose a health hazard to the population.

Acknowledgements. We thank the St. Augustine Campus Research Fund Committee of the University of the West Indies for funding the project. We also express our thanks to the people of Matura, Rampanalgas, Salybia, and Toco for their hospitality, kindness, and patience. Thanks also go to Dr. Simeon for helping in the statistical analysis of the data and to Nadira Seepersadsingh for her technical support. We are grateful to Joanne SmartMcKain for typing the manuscript.

\section{REFERENCES}

1. Umoh JU, Adesiyun AA, Adekeye JO. Epidemiological features of an outbreak of gastroenteritis/cholera in Katsina, Northern Nigeria. J Hyg (Camb) 1983;91(1):101-111.

2. Lassen J. Yersinia enterocolitica in drinking water. Scand J Inf Dis 1972;4:25-27.

3. Swerdlow DL, Woodruff BA, Brady RC. A waterborne outbreak in Missouri of Escherichia coli O157:H7 associated with bloody diarrhea and death. Ann Intern Med 1992; 117(10):812-819.

4. Mackenzie WR, Schell WL, Blair KA, Addiss DG, et al. Massive outbreak of waterborne cryptosporidium infection in Milwaukee, Wisconsin: recurrence of illness and risk of secondary transmission. Clin Inf Dis 1995; 21(1):57-62.

5. Bridgman SA, Robertson RM, Syed Q, Speed $\mathrm{N}$, et al. Outbreak of cryptosporidiosis associated with a disinfected groundwater supply. Epidemiol Infect 1995;115(3):555-566.

6. United States, Centers for Disease Control and Prevention. Assessment of inadequately filtered public drinking water-Washington, D.C., December 1993. MMWR Morb Mortal Wkly Rep 1994;43(36):661-663.

7. Robbins-Browne RN. Traditional enteropathogenic Escherichia coli of infantile diarrhea. Rev Infect Dis 1987(1):28-53.

8. Bell BP, Goldoft M, Griffin PM, Davis MA, et al. A multistate outbreak of Escherichia coli O157:H7-associated bloody diarrhea and hemolytic uremic syndrome from hamburgers. The Washington experience. JAMA 1994;272 (17):1349-1353.

9. Griffin PM, Tauxe RV. The epidemiology of infections caused by Escherichia coli O157:H7, other enterohemorrhagic E. coli, and the associated hemolytic uremic syndrome. Epidemiol Rev 1991;13:60-98.

10. Reiff FM, Roses M, Venczel L, Quick R, Witt VM. Low-cost safe water for the world: a practical interim solution. J Public Health Policy 1996;17(4):389-408.

11. Raucher RS. Public health and regulatory consideration of safe drinking water. Act Ann Rev Public Health 1996;17:179-202.

12. Gerba CP, Rose JB, Haas CN. A sensitive population: who is at greatest risk? Int J Food Microbiol 1996;30:113-123.

13. Angulo FJ, Tippen S, Sharp DJ, Payne BJ, et al. A community waterborne outbreak of salmonellosis and the effectiveness of a boil water order. Am J Public Health 1997;87:580-584.

14. Pan American Health Organization. Drinking water supply. In: Volume I: Health conditions in the Americas. 1994 edition. Washington, D.C.: PAHO: 1994. pp. 274-277. (Scientific Publication No. 549).

15. Adesiyun AA, Adekeye JO, Umoh JU. Studies on well water and possible health risks in Katsina, Nigeria. J Hyg (Camb) 1983;90: 199-205.

16. Alabi DA, Adesiyun AA. Studies on microbial quality of filtered water in households of a university community in Nigeria. J Hyg (Camb) 1986;96:239-248.

17. Chongsuvivatwong V, Mo-suwan L, Chompikul J, Vitsupakom K, McNeil D. Effects of piped water supply on the incidence of diarrheal diseases in children in southern Thailand. Southeast Asian J Trop Med Public Health 1994;25(4):628-632.

18. Trinidad and Tobago, Central Statistical Office. Census report: 276. Port of Spain, Trinidad: CSO; 1990.

19. Knight CL, Burgess N. Caroni River Basin study report on water supply. Port of Spain, Trinidad: Government of Trinidad and Tobago Water and Sewage Authority; March 1977.

20. LeChevallier MW, Cameron SC, McFeters GA. New medium for improved recovery of coliform bacteria from drinking water. Appl Environ Microbiol 1983;45(2):484-492.
21. Ontario Ministry of Health. Membrane filter techniques. In: Environmental bacteriology laboratory procedures manual. Toronto, Ontario, Canada: Ontario Ministry of Health, Laboratory Services Branch; 1995.

22. Macfaddin JF. Biochemical tests for identification of bacteria. New York: Williams and Wilkins; 1980.

23. Robin RS, Gould S, Bergdoll MS. Detecting the enterotoxigenicity of Staphylococcus aureus strains. Appl Microbiol 1974;28:946-950.

24. Blanco J, Gonzalez EA, Garcia S, Blanco M, Regueiro B, Bernadez I. Production of toxins by Escherichia coli strains isolated from calves with diarrhoea in Galicia (Northwest Spain). Vet Microbiol 1998;18:297-311.

25. Lopez CE, Dykes AC, Juranek DD, et al. Waterborne giardiasis: a communitywide outbreak of disease and a high rate of asymptomatic infection. Am J Epidemiol 1980;112(4): 495-507.

26. Freedman B. Sanitarian's handbook: theory and administrative practice for environmental health. New Orleans: Peerless Publishing; 1977.

27. Moore AC, Herwaldt BL, Craun GF, Calderon AK, et al. Waterborne disease in the United States, 1991 and 1992. J Am Water Works Assoc 1994;86:87-99.

28. Mascher F, Reinthaler F. Drinking water problems in tropical countries as in the example of Abeokuta, Nigeria. Appl Environ Microbiol 1979;37:744-749.

29. World Health Organization. Guidelines for drinking-water quality. Volume 2: health criteria and other supporting information. Geneva: WHO; 1993.

30. Marques LR, Abe CM, Griffin PM, Gomes TA. Association between alpha-hemolysin production and HeLa cell-detaching activity in fecal isolates of Escherichia coli. J Clin Microbiol 1995;33:2707-2709. 
31. Prada J, Baljer G, DeRycle J, Steinruck H, et al. Characteristics of alpha-hemolytic strains of Escherichia coli isolates from dogs with gastroenteritis. Vet Microbiol 1991;29:59-73.

32. Jann B, Jann K. Structure and biosynthesis of the capsular antigens of Escherichia coli. Curr Topics Microbiol Immunol 1990;150:19-42.

33. Yerushalmi Z, Smorodinsky NI, Naveh MW, Rou EZ. Adherence of pili of avian strains of Escherichia coli O78. Infect Immun 1990;58(4): 1129-1131.

34. Bree A, Dho M, Lafont JP. Comparative infectivity for axenic and specific-pathogen-free chickens of $\mathrm{O} 2$ Escherichia coli strains with or without virulence factors. Avian Dis 1989; 33(1):134-139.

35. March SB, Ratnam S. Sorbitol-MacConkey medium for detection of Escherichia coli
O157:H7 associated with hemorrhagic colitis. J Clin Microbiol 1986;23(5):869-872.

36. Adesiyun AA. Prevalence of Listeria spp., Campylobacter spp., Salmonella spp., Yersinia enterocolitica and toxigenic Escherichia coli on meats and seafoods in Trinidad. Food Microbiol 1993;10:395-403.

37. Adesiyun AA, Webb LA, Romain H, Kaminjolo JS. Prevalence and characteristics of E. coli strains isolated from milk and feces of cows on dairy farms. J Food Protec 1997;60: 1174-1181.

38. Karmali MA. Infection by verocytotoxinproducing Escherichia coli. Clin Microbiol Rev 1989;2:15-38.

39. Jackson SG, Goodbrand RB, Johnson RP, Odorico VG, et al. Escherichia coli O157:H7 diarrhoea associated with well water and in- fected cattle on an Ontario farm. Epidemiol Infect 1998;120:17-20.

40. Dev VJ, Main M, Gould I. Waterborne outbreak of Escherichia coli O157. Lancet 1991;337: 1412.

41. Gyles CL. Escherichia coli. In: Gyles CL, ed. Pathogenesis of bacterial infections in animals. Ames, Iowa: Iowa State University; 1993. p 164-189.

Manuscript received on 14 April 1999. Revised version accepted for publication on 3 March 2000.

RESUMEN Se realizó un estudio transversal en cuatro comunidades rurales del nordeste de la isla de Trinidad para determinar la calidad microbiológica de los suministros domésticos de agua y la relación entre dicha calidad y el origen del agua y los recipientes utilizados para su almacenamiento. Entre las 167 muestras de agua doméstica analizadas, se detectaron coliformes totales en $132(79,0 \%)$, coliformes fecales en $102(61,1 \%)$ y Escherichia coli en 111 (66,5\%). Hubo diferencias significativas entre los pueblos con respecto a la proporción de muestras contaminadas con coliformes $(P<0,001)$ y E. coli $(P<0,001)$. De las 253 cepas de E. coli estudiadas, $4(1,6 \%)$ eran mucoides, $9(3,6 \%)$ hemolíticas y $37(14,6 \%)$ no fermentadoras de sorbitol. De 69 aislados de E. coli en los que se analizó esta característica, 10 (14,5\%) fueron citotóxicos para las células Vero. Veintiocho de $200(14,0 \%)$ aislados de E. coli analizados pertenecían a serogrupos enteropatógenos. El origen más frecuente del agua fueron las fuentes (57 de los 167 domicilios; $34,1 \%)$. Ciento diecinueve domicilios $(71,3 \%)$ recibían agua tratada (agua canalizada hasta el domicilio, de fuente o de camión cisterna), mientras que los otros $48(28,7 \%)$ utilizaban agua no tratada (de lluvia, ríos/arroyos o pozos) como principal suministro de agua. El tipo de recipiente de almacenamiento en el domicilio se asoció con la contaminación por coliformes. El agua almacenada en bidones, barriles o cubos tenía mayores probabilidades de albergar coliformes fecales $(74,2 \%$ de las muestras) que el agua almacenada en tanques ( $53,3 \%$ de las muestras), incluso después de controlar el efecto del origen del agua $(P=0,04)$. En comparación con el agua de otras fuentes, el agua canalizada hasta las casas tenía una probabilidad significativamente menor de estar contaminada por coliformes totales $(56,9 \%$ frente a $88,8 \% ; P<0,001)$ y coliformes fecales $(41,2 \%$ frente a $69,8 \%, P<0,01)$, incluso después de tener en cuenta el tipo de recipiente de almacenamiento. Sin embargo, la contaminación fecal no se asoció con el origen tratado o no tratado del agua. Concluimos que el agua para beber de las comunidades rurales de Trinidad era en general no apta para el consumo humano debido a su contaminación tanto en el origen como durante el almacenamiento en el domicilio. 